\title{
18. CLAY SEDIMENTATION AND PALEOENVIRONMENT IN THE SHIKOKU BASIN SINCE THE MIDDLE MIOCENE (DEEP SEA DRILLING PROJECT LEG 58, NORTH PHILIPPINE SEA)
}

\author{
Hervé Chamley, Sédimentologie et Géochimie (ERA 764 CNRS), Université de Lille I, Villeneuve d'Ascq, \\ France
}

\begin{abstract}
Clay sedimentation in Shikoku (back-arc) Basin began in the early middle Miocene; this sedimentation was accompanied by basaltic intrusions, with moderate alteration under closed conditions (smectite, sometimes chlorite and talc). After a short period of sedimentation of brown pelagic clay, dominated by in situ smectite formation, hemipelagic deposits become common at DSDP Sites 442, 443, and 444 ; these deposits show various and diachronous mineralogical changes. Miocene sedimentation was influenced by volcanism; volcanogenic materials were derived chiefly from adjacent volcanic arcs by subaerial alteration and erosion. Latest-Miocene to Pleistocene clay sedimentation was progressively influenced by continental climatic factors (irregular world cooling). The major sources of clay minerals in Shikoku Basin are recognized: illite and chlorite from Japan; smectite from volcanic arcs; kaolinite supplied from the southwest by the Kuroshio Current, whose influence probably starts from the initiation of the marine basin; vermiculite, attapulgite, and most of the irregular mixed-layer clays from Asia. The main sources of detritus changed with time, mainly because of vertical movements of volcanic ridges, forming temporary barriers against oceanic circulation. The Iwo Jima and Kyushu-Palau ridges emerged during the Miocene, and the Kyushu-Palau Ridge subsided in two major stages during the Pleistocene. Thus the sedimentary clays of Shikoku Basin, for the middle Miocene to the present, are indicators of geodynamics, currents, and climate.
\end{abstract}

\section{INTRODUCTION AND METHODS}

During DSDP Leg 58, three sites in the vicinity of the expected spreading center of Shikoku inter-arc basin were drilled in the northern Philippine Sea. At Sites 442, 443 , and 444 a subcontinuous Miocene to Pleistocene series overlying oceanic basalts was penetrated (see site chapters, this volume). Site 442 lies on the eastern flank of the submerged Kyushu-Palau ridge, whereas Sites 443 and 444 are on a clastic wedge bordering the Iwo Jima-Bonin Ridge (Figure 1).

Methods are explained in the companion paper by Chamley in this volume.

\section{RESULTS}

\section{Site $\mathbf{4 4 2}$}

Sixty samples from Site 442 were studied. Analyses were made on a few samples of pillow and flow basalt sills, and on samples of the thin pelagic mud of the early to middle Miocene and the thick hemipelagic mud of the Miocene to Pleistocene. Results are shown in Figure 2.

\section{Basalt}

Altered basalts contain little clay, dominated by wellcrystallized smectite, which forms large, board-like sheets (Plate 1) characteristic of the saponite group
(Mg-Al smectite; Beutelspacher and Van der Marel, 1968; Gard, 1971). The rare-earth elements are typical of tholeiitic basalts and do not show equilibration with sea water (absence of $\mathrm{Ce}$ negative anomaly; C. Courtois, pers. comm.). Smectite is accompanied by a little feldspar, and local traces of chlorite and mica-illite.

\section{Pelagic Mud}

Non-biogenic brown mud and clay of the early to middle Miocene (289 to $276 \mathrm{~m}$ sub-bottom), separated from underlying basalt flows by $40 \mathrm{~cm}$ of non-clayey, recrystallized limestone, are mineralogically homogeneous. Highly crystallized smectite is the dominant species, occurring as sheets without peculiar morphology. The sheets are accompanied by sparse, short laths, possibly $\mathrm{Fe}$-smectites (nontronites) or altered fibrous clays (Plate 1). Rare-earth elements show a slight decrease in light elements, suggesting little basalt influence on clay genesis; there is no evidence of seawater influence (C. Courtois, pers. comm.). Besides smectite, there are small amounts of illite, kaolinite, feldspar, and sometimes chlorite and quartz. Zeolites have not been identified by X-ray diffraction, either in the clay fraction or in the bulk material. Amorphous, diffuse iron oxides are abundant, commonly associated with metallic micronodules. 


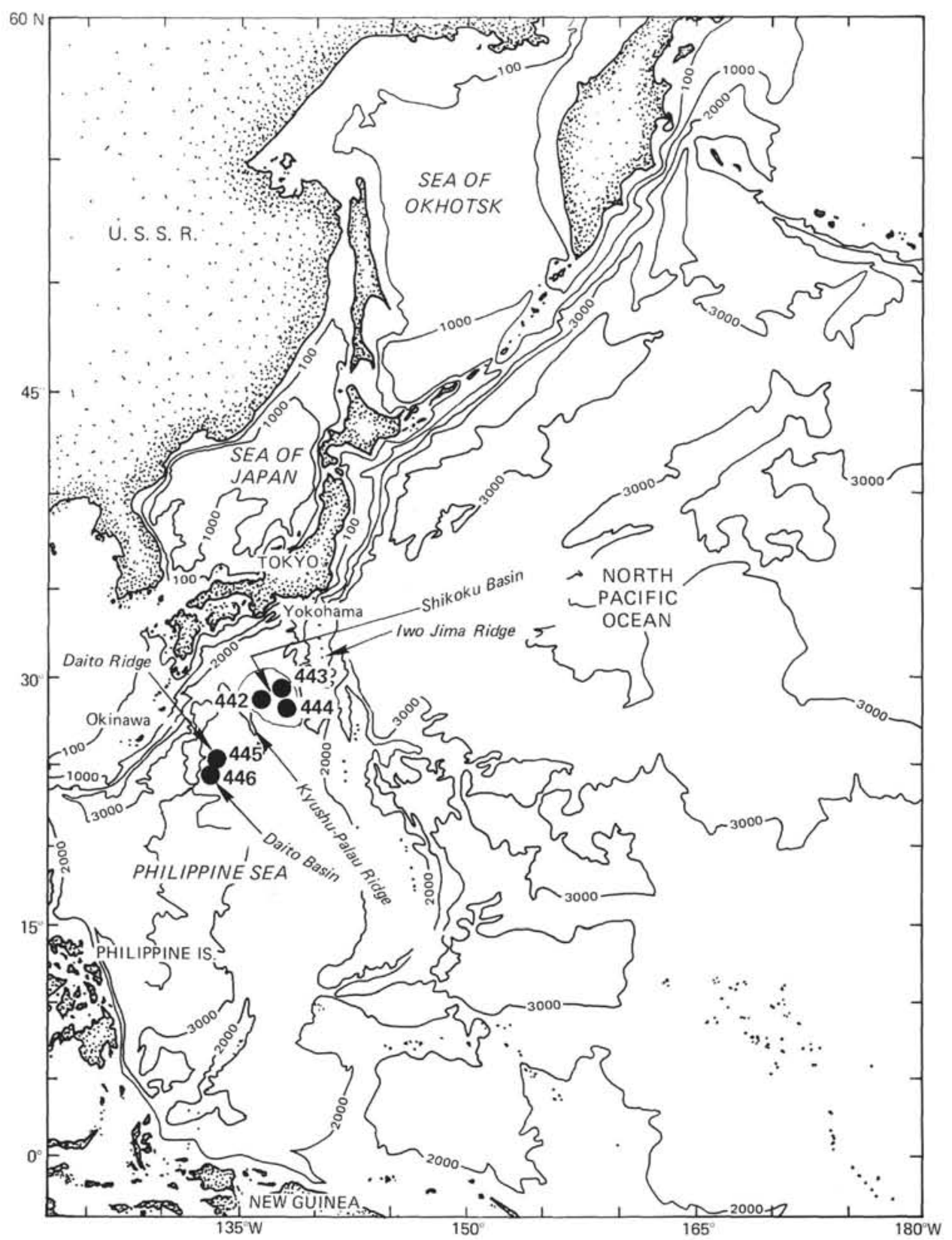

Figure 1. Leg 58 sites in the Philippine Sea.

\section{Hemipelagic Mud and Clay}

The late-Miocene to late-Pleistocene sedimentary column shows an obvious mineralogical stratigraphy. Above a transitional grayish, ashy mud marked by high amounts of smectite, late-Miocene yellow to brownish mud is diversified: moderately well crystallized to poorly crystallized smectite (35-65\% of clay minerals), fairly wellcrystallized illite $(20-30 \%)$, chlorite $(5 \%)$, kaolinite (5$10 \%$ ), irregular mixed-layer clays (average $10 \%$ : illitesmectite, illite-vermiculite, chlorite-smectite, chloritevermiculite; smectite components most abundant), and feldspars. Sediments of Core 26 contain 5 per cent vermiculite and abundant vermiculitic mixed-layer clays. Atta- pulgite (palygorskite) occurs in trace amounts, often associated with quartz and sometimes with goethite. The clay color and mineralogy of the Pliocene sediments are very similar to those of the late Miocene. Attapulgite occurs throughout as short, altered fibers. Vermiculite is absent.

Pleistocene clay assemblages differ radically from those of older sediments. Small amounts (5-15\%) of poorly crystallized smectite is accompanied by 5 to 30 per cent of various irregular mixed-layer clays (mixtures of so-called illite, chlorite, smectite, and vermiculite layers). The most abundant species are illite (30-50\%) and chlorite (10-20\%). Typical vermiculite occurs throughout in variable proportions $(5-30 \%)$, whereas attapul- 


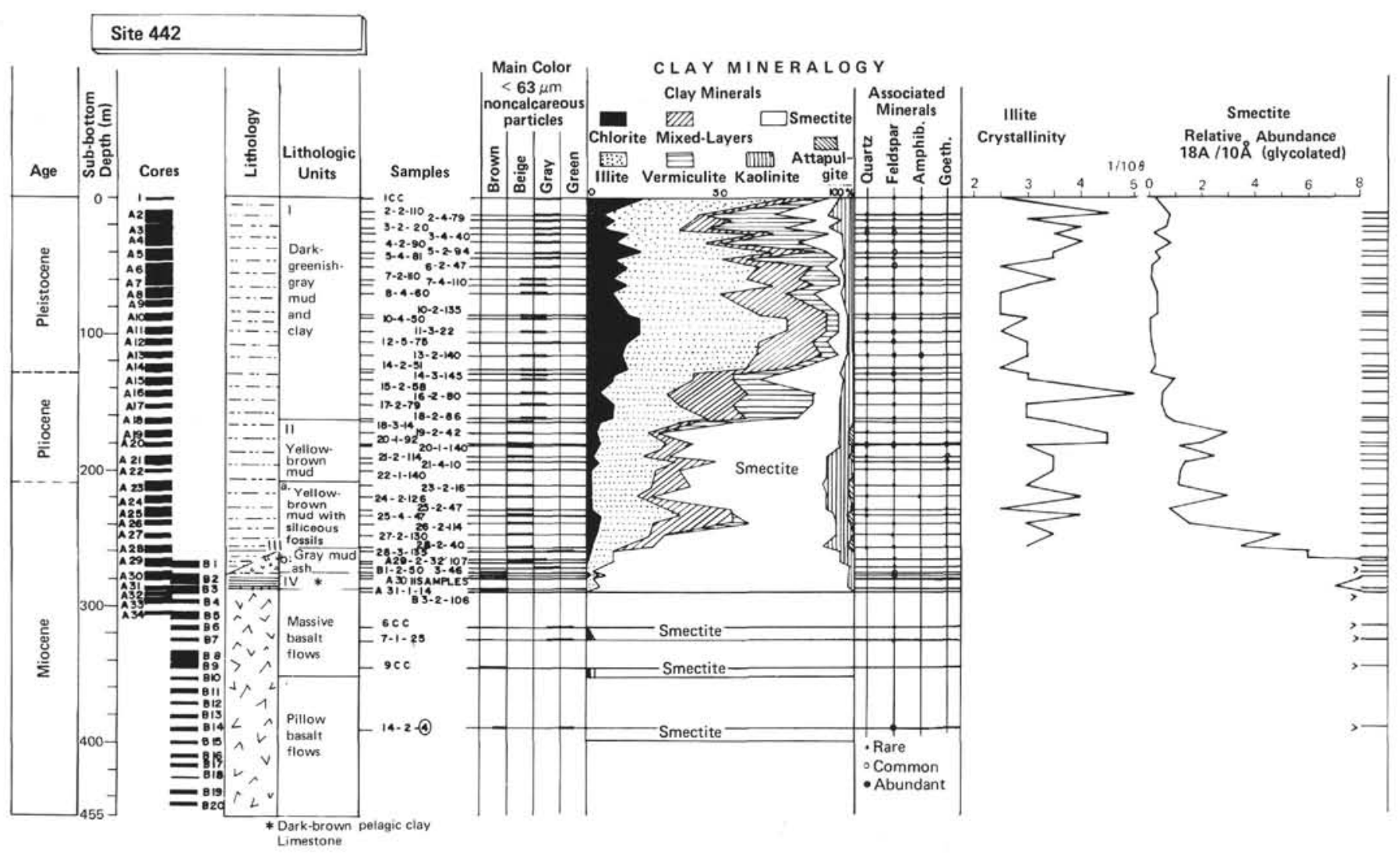

Figure 2. Clay-mineralogy data for Site 442, Shikoku Basin.

gite is lacking. Kaolinite is constant $(5 \%)$, as are feldspars, quartz, and amphiboles. In the Pleistocene, there are alternations of relatively abundant chlorite and illite (corresponding to better crystallinities and to higher amounts of associated non-clay minerals) and, when chlorite and illite decrease, increases in vermiculite (often together with irregular mixed-layer clays, smectite, or kaolinite).

\section{Site 443}

Site 443 , northeast of Site 442 , shows a similar sequence; however, it is marked by more calcareous and pyroclastic components. The varicolored hemipelagic muds of the middle Miocene to late Pleistocene were systematically analyzed by X-ray diffraction ( 57 samples) and transmission electron microscopy showing a quantitative clay stratigraphy (Figure 3 ) different from that of Site 442 .

Middle-Miocene, gray to yellowish-gray sediments immediately overlying the basalt (Cores 49 and 48) contain much highly crystallized smectite, and little chlorite, illite, kaolinite, and feldspars. Immediately above occurs a mineralogical diversification: smectite abundance and crystallinity decrease, while illite, irregular mixed-layer clays (chiefly illite-smectite, lesser chloritesmectite, very few vermiculitic components), chlorite, and kaolinite increase.

Late-Miocene yellowish mudstone and clayey nannofossil ooze, Pliocene yellowish-gray clay and mud, and Pleistocene gray mud with ash layers contain similar clay assemblages; this differs from Site 442 , where the Pleistocene does not resemble the Mio-Pliocene. Illite and poorly crystallized smectite are the dominant minerals, accompanied by fairly abundant chlorite and irregular mixed-layer clays, and by small amounts of kaolinite. Vermiculite is often present but sparse (traces to $5 \%$ ). Attapulgite has not been identified on the X-ray diagrams. Quartz and feldspars are ubiquitous; amphiboles appear in the most recent sediments. Upwards in the section, there is an increase in chlorite content and illite crystallinity and a decrease in smectite content. There is no relationship between smectite abundance or crystallinity and the occurrence of glass and ash layers.

Smectite at Site 443 is less abundant than at Site $\mathbf{4 4 2}$ in the late Miocene and Pliocene, and more abundant in the early and, especially, late Pleistocene. In a general way, vermiculite, irregular mixed-layer clays, and kaolinite are less abundant at the eastern site (443), and attapulgite is not recognized; on the other hand, illite and chlorite occur in larger amounts, until the lower Pleistocene. At both sites, vertical changes in illite and chlorite contents are opposite to those of vermiculite and (or) mixed-layer clays and disordered smectite.

\section{Site 444}

Site 444 was drilled 45 miles southeast of Site 443. Middle-Miocene to late Pleistocene hemipelagic mudstone and mud with calcareous, siliceous, or volcanic components overlie basalt flows, the last of which at least appears to be a sill in terrigenous sediments. 


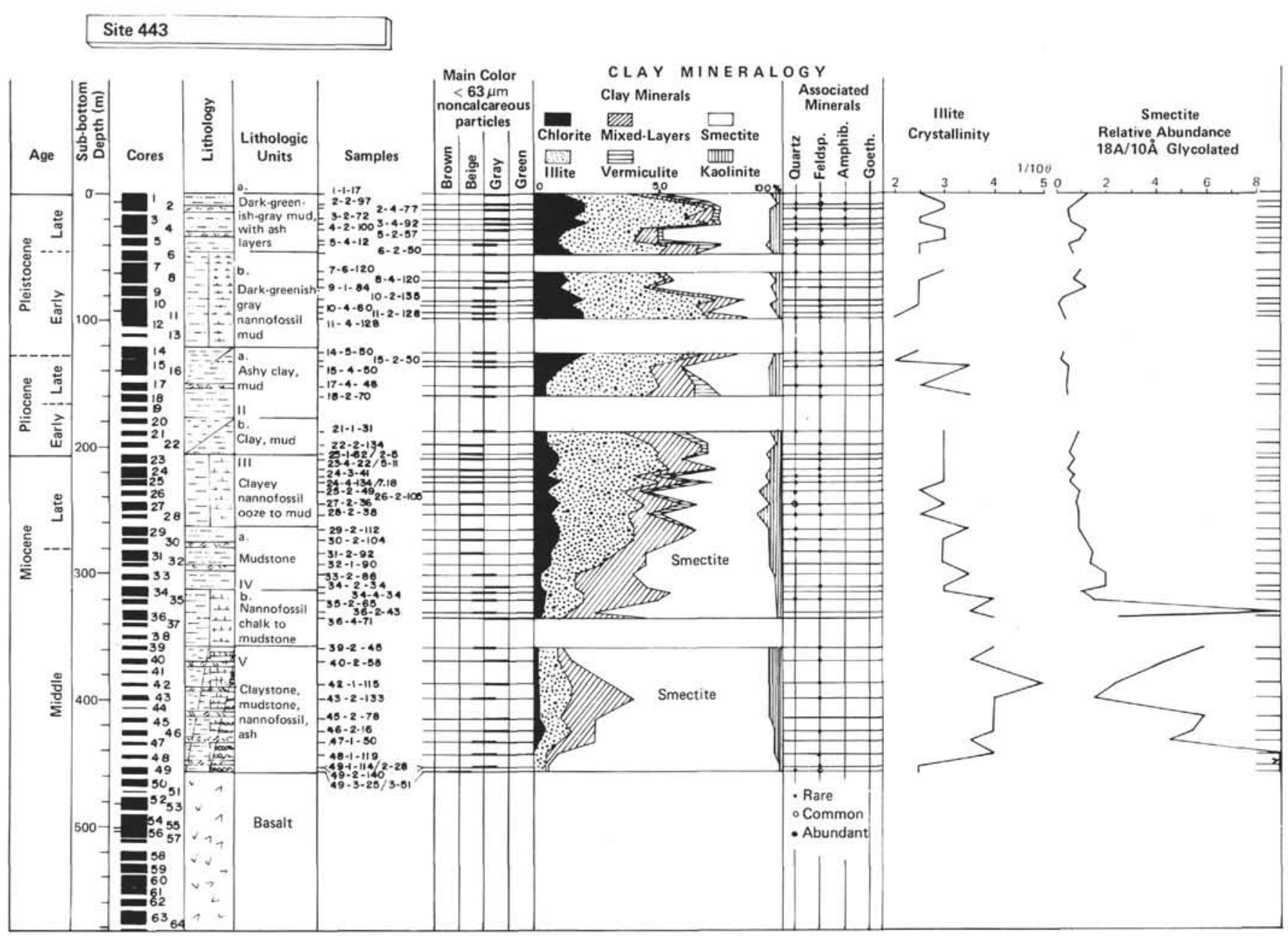

Figure 3. Clay-mineralogy data for Site 443, Shikoku Basin.

Pelagic deposits consist of only $1 \mathrm{~m}$ of reddish-brown, violet, and grayish mud, with occasional calcareous nannofossils and zeolites, immediately above the main basalt flows. Forty-five samples were studied to determine their mineral content (Figure 4).

\section{Basalt}

Section 444A-27-5 (Piece 5) contains an altered basalt whose clay fraction consists of highly crystallized smectite $(95 \%)$, with small amounts of chlorite and feldspar and traces of illite. Core 444A-19, CC represents altered rock from the top of the last basaltic sill; it contains much well-crystallized smectite and chlorite, with talc and feldspar; the bulk material is feldspar-rich chlorite.

\section{Pelagic Clay}

The first recovered marine sediments (Section 444A23-1) show a peculiar mineralogy. In the bulk sediment, smectite, attapulgite, quartz, and opal-CT are recognized. The clay fraction contains (besides well-crystallized smectite which resembles saponite), small amounts of chlorite, illite, quartz, and feldspar, and three unusual minerals: attapulgite, much opal-CT, and small amounts of probable pyrophyllite. Electron microscopy shows a peculiar morphology (Plate 2): large and broad, refringent, board-like sheets (probable saponite) are bordered by thin, well-shaped laths (probable attapulgite, possible pyrophyllite?); these occur together with common clay sheets.

\section{Hemipelagic Clay}

The middle-Miocene to late-Pleistocene clay sedimentation at Site 444 was similar to that described for Site 443, and distinct from that described for Site 442 . Middle-Miocene sediments are smectite-rich $(70 \%)$, but the mineral is moderately well to poorly crystallized, and its abundance decreases upward. From the late Miocene to the Pleistocene, smectite and illite are the dominant species, accompanied by chlorite (increasing from latest-Miocene levels), irregular mixed-layer clays (chiefly illite-smectite and chlorite-smectite), kaolinite, quartz, and feldspar. Vermiculite occurs only locally (latest Miocene) in small amounts; attapulgite was not detected. Upward, smectite decreases slightly, while the crystallinity of primary minerals increases, and amphiboles appear. There is an inverse relationship between illite and chlorite, and mixed-layer clays, smectite, and kaolinite. The only differences between the Site 444 sediments and the Site 443 sediments are the following: vermiculite is still rarer; illite and chlorite are a little less 


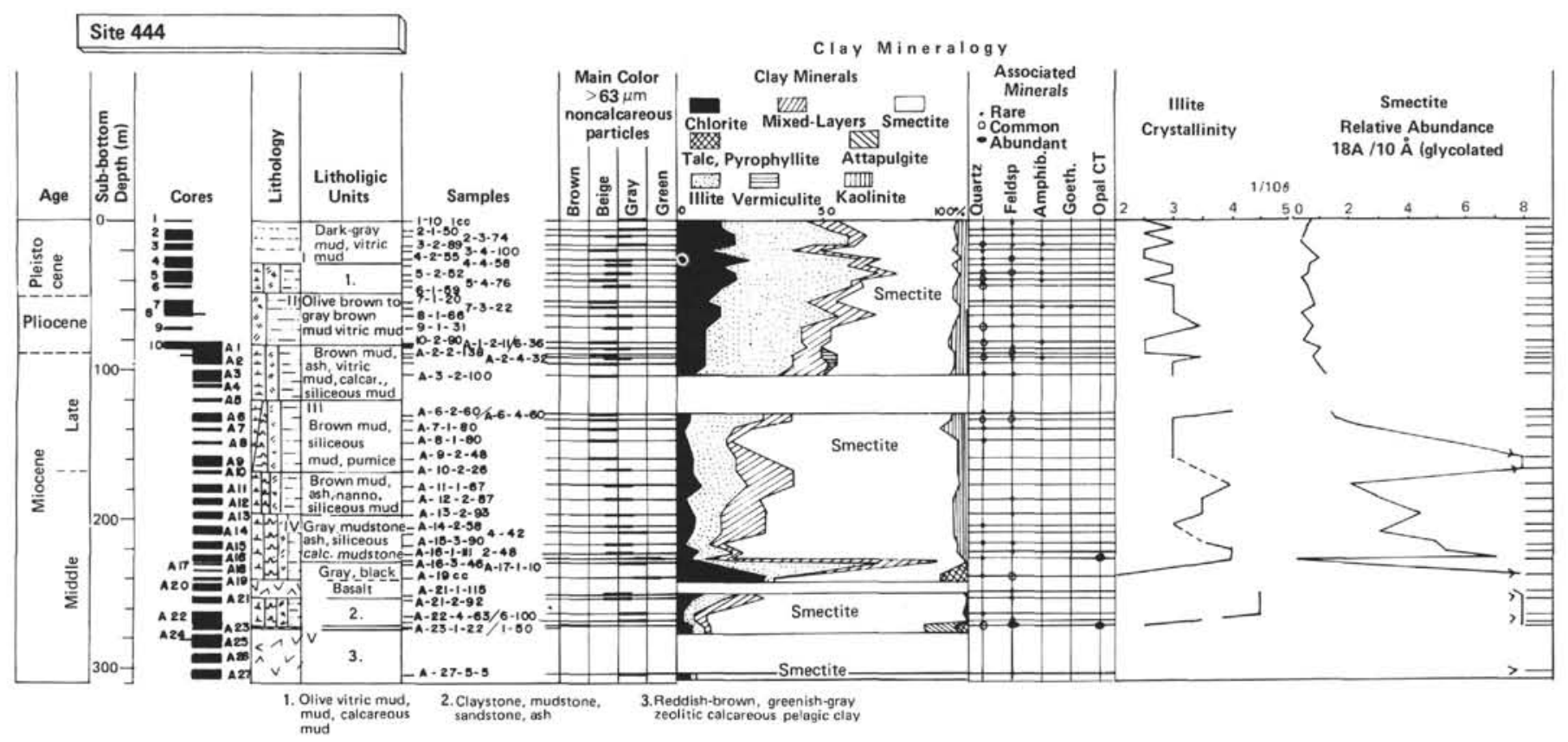

Figure 4. Clay-mineralogy data for Site 444, Shikoku Basin.

abundant; smectite is more abundant in the upper Miocene and can be related to increased volcanism (ash and glassy mud).

\section{ORIGINS OF CLAY MINERALS}

\section{Illite, chlorite}

The typically detrital minerals illite and chlorite, and associated quartz, feldspar, and amphibole, are derived from continental erosion of igneous, metamorphic, or old sedimentary rocks. These rocks crop out widely on the southern Japanese Islands and in eastern Asia; they are responsible for the major part of primary mineral supplies during the late Cenozoic, as they do at the present time (Aoki and Oinuma, 1974; Aoki et al., 1974; Huang and Chen, 1975; Murdmaa et al., 1977; Kolla et al., in press). The lower the volcanic activity and pedogenic weathering, the stronger the primary mineral supply. Note, however, that chlorite can occur locally in small amounts from the alteration of basalt.

\section{Irregular Mixed-Layer Clays}

In most marine sediments, mixed-layer clays are inherited from alteration of continental illite, chlorite and smectite; they form under conditions of moderate hydrolysis (Millot, 1964). The relative abundance of irregular illite-smectite, chlorite-smectite, - and sometimes less-degraded illite-vermiculite and chlorite-vermiculite-in the Shikoku Basin in the upper Cenozoic indicates a temperate and humid climate.

\section{Vermiculite}

The occurrence of vermiculite in the northern Philippine Sea was unexpected, judging from previous data of DSDP Legs 6 and 31 (Rex et al., 1971; Cook et al., 1975). In the Leg 58 cores, vermiculite is relatively abundant and constant at the western site (442) only, both other sites $(443,444)$ being devoid of vermiculite or with only sporadic occurrences. Holocene sediments do not contain vermiculite, except in the vicinity of Okinawa (Aoki and Oinuma, 1974). This agrees with the rarity of the mineral in the younger sediments drilled during Leg 58 (Figures 2 and 3). Vermiculite is chiefly derived from alteration under temperate humid climate, as are irregular mixed-layer clays: parents materials are illite, chlorite, and smectite, incompletely altered by continental weathering. These minerals chiefly originated in eastern Asia and the Ryukyu Islands (Aoki and Oinuma, 1974), which explains the presence of vermiculiterich sediments on a clastic wedge of western origin at Site 442. Marine and eolian transport may have contributed to this western supply.

\section{Kaolinite}

Warm and humid continental climates lead to active pedogenic formation of kaolinite (Millot, 1964), which agrees with the preferential distribution of the mineral in low-latitude Holocene sediments of the Pacific Ocean (Griffin et al., 1968; Aoki, 1976). In the northern Philippine Sea and Japan Sea, kaolinite is supplied from southwestern Asia by warm surficial currents (Kuroshio, Tsushima) (Aoki et al., 1974). The same phenomenon probably occurred during the entire late Cenozoic, as suggested by the higher average kaolinite contents at Site 442 , compared to both of the more eastern sites (443 and 44) (Figure 5).

\section{Attapulgite (palygorskite)}

Attapulgite is restricted to the Neogene hemipelagic sediments of Site 442 , and the dispersed, rare, and broken fibers seem to have an eastern detrital origin, as does vermiculite. The local and rare occurrence of attapulgite in the violet pelagic mud of Site 444 does not 

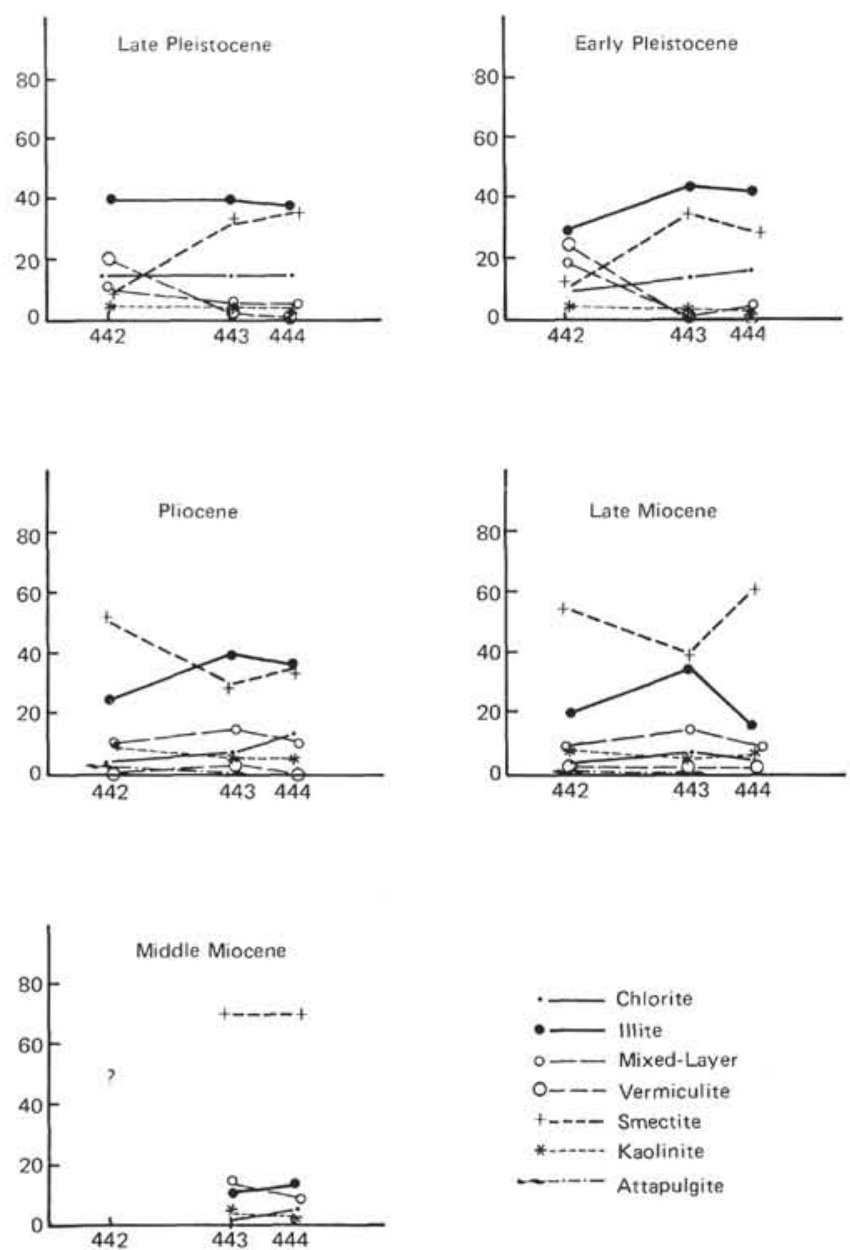

Figure 5. Geographic distribution of clay minerals in clay sedimentation since the formation of the Shikoku Basin.

necessarily indicate an in situ origin, for the mineral is not present in the overlying hemipelagic sediments. Attapulgite probably has come partly from erosion of sedimentary rocks in Asia, which had previously formed under arid conditions (see for instance Melieres, 1978; Timofeev et al., 1978; Chamley, in press).

\section{Smectite}

Deciphering the origin of smectite is a difficult problem, because the mineral sources can be many and very different in a given period. Consider the main lithofacies occurring in the Shikoku Basin.

\section{Basalt}

An autochthonous origin of well-crystallized $\mathrm{Mg}-\mathrm{Fe}$ smectite by in situ alteration of veins and vesicles of basic volcanic rocks is obvious here, and is well known from the literature (Peterson and Griffin, 1964; Seyfried et al., 1978; Sugisaki, this volume). Talc and chlorite identified in basalts have a similar genesis, as do celadonite, zeolite, and other minerals. Note, however, the low quantities of all these secondary minerals compared to fresh or weakly altered basalt, and the probable isolation of basalt from sea-water influences (rare-earth-element data of C. Courtois, pers. comm.) This can be clearly understood by considering the distance from the basalt/sediment interface (up to $100 \mathrm{~m}$ at the Shikoku Basin sites).

\section{Pelagic Clay and Mud}

The high abundance and crystallinity of smectite, its peculiar morphology and association with fibrous clays (Plate 2), and its occurrence in an interval of slow sedimentation favorable to genesis of iron-manganese mud and micronodules indicate in situ formation in the brown, reddish, and violet sediments immediately overlying basalt. This genesis-in brown, ferruginous sediments-seems to be common at the bottom of Pacific sedimentary columns (Cronan, 1973; Aoki et al., 1974; Bonatti et al., 1979; Murdmaa et al., 1977). Basalt probably influences this genesis, possibly combined with hydrothermal activity and diagenesis (probable occurrence of nontronite, attapulgite, and pyrophyllite). Sea-water influence is not obvious from the rare-earth elements (C. Courtois, pers. comm.), which differ from those typical of pelagic clays formed in situ (Courtois and Hoffert, 1977). Note that some clay minerals associated with smectite are typically detrital (illite, kaolinite).

\section{Hemipelagic Sediments}

The most probable and common origin of smectite in the Shikoku Basin lies in the volcanic rocks forming the surrounding late-Cenozoic islands arcs (Iwo JimaBonin, Ryukyu, Japan) and presently submerged ridges (Kyushu-Palau) (Huang and Chen, 1975; Murdmaa et al., 1977; Kolla et al., in press).

The following facts suggest that smectite deposits are not chiefly derived from submarine, in situ evolution of volcanic materials, but from subaerial erosion and transport into the marine basin: (1) smectite abundance does not correspond to the abundance of volcanic glass and ash whether dispersed or present in distinct beds; the locally abundant volcanoclastic sediments in the Pleistocene are marked by little smectite; (2) a strong contrast exists between the highly crystallized smectite obviously derived from volcanic alteration (basalt) and the poorly crystallized smectite in common sediments; (3) smectite occurs in hemipelagic deposits typical of open-sea conditions, in which the mineral is intimately dispersed among common detrital minerals.

The hypothesis of an allochthonous volcanogenic source for smectite can be argued when considering the very large emerged areas of volcanic rocks during the first stages of formation of the Shikoku Basin, precisely when the poorly crystallized smectite was abundant in terrigenous clayey sediments. Note that during the most recent Cenozoic epochs, a part of the altered smectite probably results from continental alteration of nonvolcanic rocks, as in many areas of the world today (Griffin et. al., 1968), particularly in eastern Asia and Japan (Kobayashi et al., 1964; Aoki and Oinuma, 1974; Aoki et al., 1974).

To summarize, except in basalts, rare ashy beds, and thin pelagic clays overlying basalts, clay minerals in the 
late-Cenozoic deposits of the Shikoku back-arc basin are essentially derived from the alteration and erosion of emergent rocks. The distribution of each mineral at the three DSDP sites and its main distribution characteristics in continental formations and recent sediments permit schematization of the dominant detrital sources (Figure 6): Japan, and then eastern Asia, for chlorite and illite; Asia for vermiculite and attapulgite; volcanic arcs for smectite; southwest Asia through Kuroshio for kaolinite; and Japan, Asia, and the island arcs for irregular mixed-layer clays.

\section{SIGNIFICANCE OF CHRONOLOGICAL CHANGES}

Average clay-mineral abundances for the middle Miocene to the late Pleistocene are shown on Figure 7. There is a lack of diagenesis even at depth: smectite, a mineral unstable in deep zones of diagenesis, is very abundant in the oldest recovered sediments. Moreover, it is poorly crystallized and associated with illite, whose crystallinity is poorer than in younger sediments.

A most important fact is an irregular decrease of smectite abundance with time, which occasions the relative increase of various other species (illite, chlorite, locally vermiculite). A similar trend appears from the routine X-ray analyses done for Sites 296 and 297 of DSDP Leg 31 in the Philippine Sea (Cook et al., 1975). This important mineralogical variation can be interpreted in two ways:

1. Geodynamic changes. The development of volcanic areas during the first stages of oceanic basin formation favored alteration processes and smectite production. This was probably the case when the Shikoku Basin formed during Miocene time. The ridge systems were very active, and large volcanic arcs emerged (as occurred at other times in other areas: e.g., Rockall Plateau, North Atlantic; Debrabant et al., 1979). After these first stages, emergent volcanic rocks probably diminished because of the cooling of oceanic crust and subsequent subsidence (Thiede, 1977). As a consequence, alteration processes decreased together with subaerial formation of smectite. Arguments for such an interpretation are given by (1) the abundance of volcanoclastic materials interbedded in the first smectite-rich

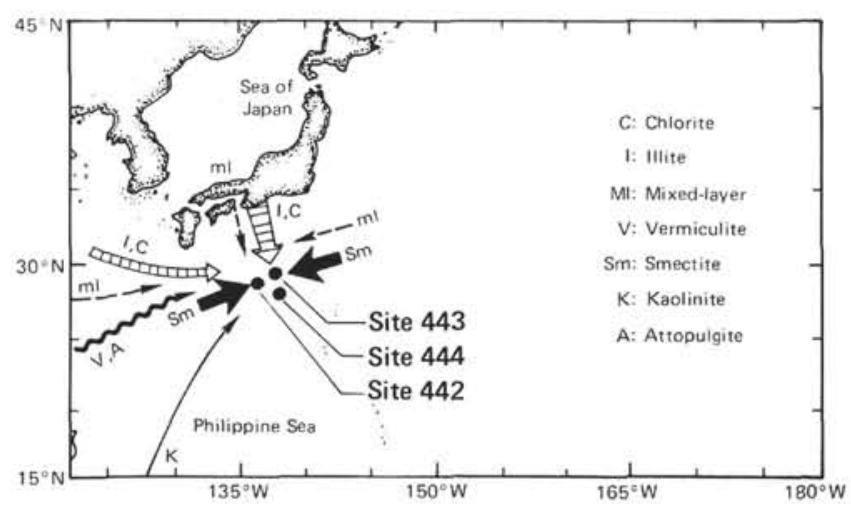

Figure 6. Main sources of sedimentary clay components in the Shikoku Basin.
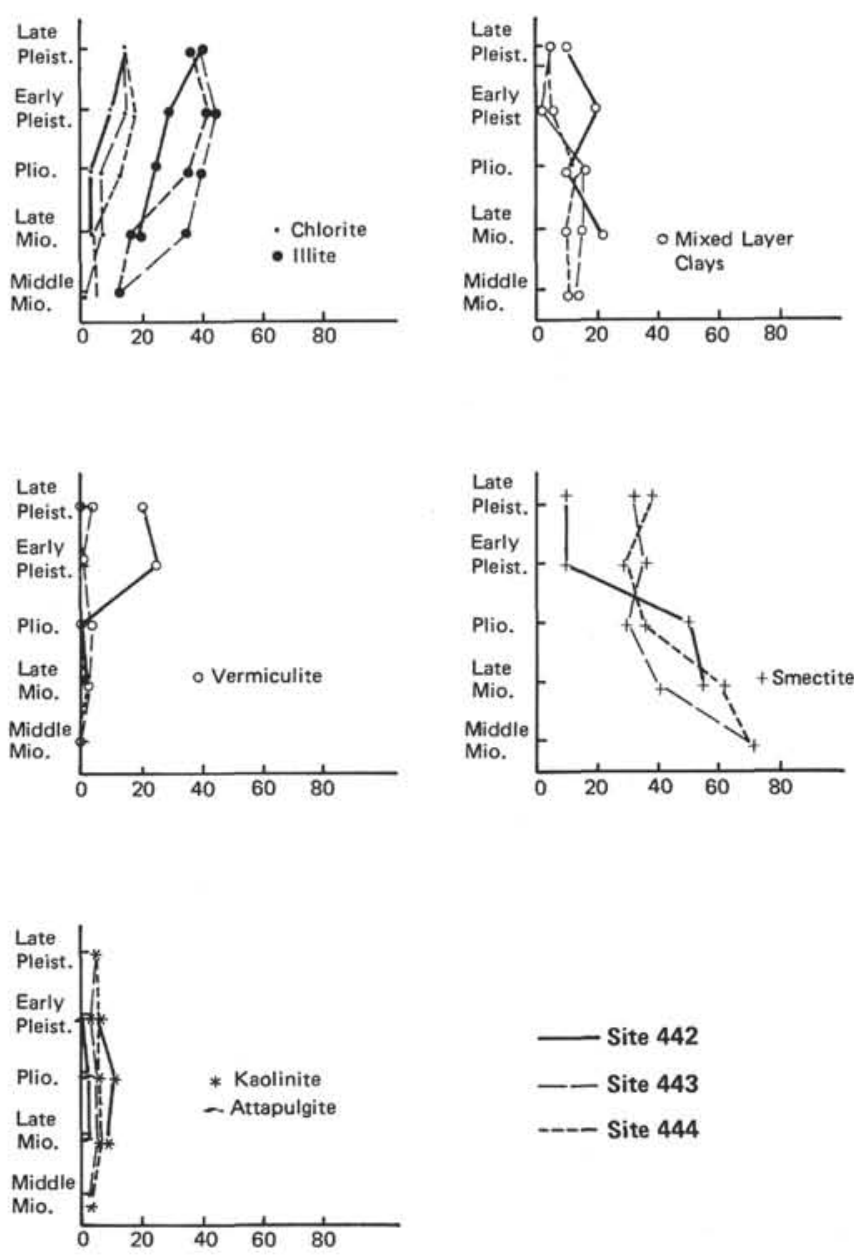

Figure 7. Chronological distribution of clay minerals in Shikoku Basin DSDP sites.

hemipelagic sediments, (2) the correspondence between the relatively high deposition rate of the first hemipelagic sediments and the high smectite content, which suggests strong erosion of extensive volcanic areas of high-relief, followed by a decrease in relief and detrital supply, and (3) the persistence, until the upper Pleistocene, of relatively smectite-rich sediments at Sites 443 and 444 , which are closer to present-day volcanic outcrops (outer arc) than Site 442.

2. Climatic changes. Early-Cenozoic epochs favored pedogenic formation of smectite from various kinds of rocks, because of arid climates with strong seasonal contrasts in humidity (Paquet, 1969; Chamley, 1979 Chamley et al., 1979). Land masses surrounding the Philippine Sea when the Shikoku Basin formed could have had such climates, which with volcanic activity would produce smectite. Differences in smectite abundance at the three Leg 58 sites nevertheless show that any such climatic influence must have been minor compared to the volcanic influences.

Later, from the late Miocene to the Pleistocene, an irregular world cooling occurred, leading to a general decrease in pedogenesis and an increased supply of primary minerals (illite, chlorite, quartz, feldspars, amphiboles) and moderately altered minerals (mixed-layer 
clays, poorly crystallized smectite ) to marine sediments. Such a climatic change, also suggested by palynological studies (Tokunaga, this vol.), seems to have strongly influenced recent clay deposits in the Shikoku Basin, as shown by (1) the parallelism between the clay assemblages deposited here (as well as in Daito Ridge area; Chamley, this volume) and in the world ocean (Chamley, 1979); (2) the opposition observed in the Pleistocene between primary minerals (illite, chlorite) and pedogenic minerals (mixed-layer clays, vermiculite, altered smectite), which is also recognized elsewhere (Chamley, 1971; Hein et al., 1975) and is chiefly due to alternation of glacial and interglacial climates over land masses (variations of continental hydrolysis); (3) the increased sedimentation rates during Pleistocene time (Klein et al., this vol.), when the glacial-interglacial regime favored sealevel changes and variations in pedogenic processes and erosion; and (4) the peculiar occurrence of vermiculite, a mineral often linked to cooler and wetter climate, in the uppermost Miocene, corresponding to a major world cooling (Shackleton and Kennett, 1975).

To summarize, clay sedimentation in the Shikoku Basin since its formation appears to have been controlled mainly by geodynamic factors from the early to late Miocene, and by climatic factors from the latest Miocene to the present. This evolution from one influence to the other one is schematically illustrated in Figure 8. Note that kaolinite abundance is unaffected, which suggests the existence of major current systems (Kuroshio) in the northern Philippine Sea since the early stages of basin formation.

\section{SIGNIFICANCE OF GEOGRAPHICAL CHANGES WITH TIME}

The general geographic distribution of clay minerals in Shikoku Basin sites is summarized on Figure 5.

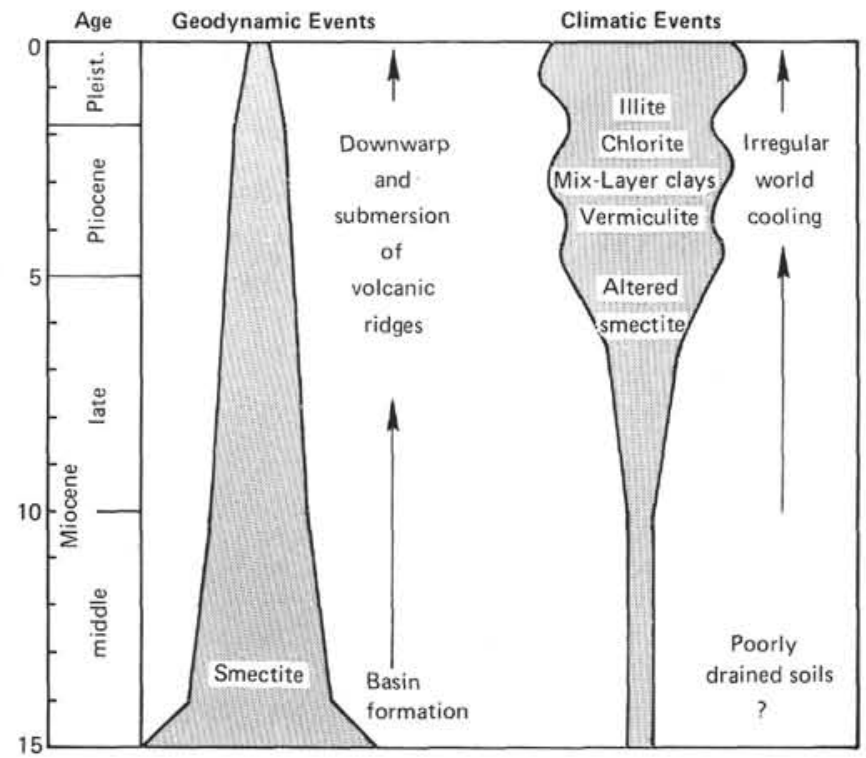

Figure 8. Chronological variations in clay sedimentation since the formation of the Shikoku Basin.
After the first pelagic deposits, middle-Miocene hemipelagic sedimentation at Sites 443 and 444 included massive supplies of smectite, corresponding (1) to the formation of a clastic wedge flanking the Iwo Jima Ridge, and (2) to a high sedimentation rate (Klein et al., this vol.). Clay minerals reflect strong eastern supplies from the outer arc, which probably was widely emergent and subject to weathering and erosion.

During the late Miocene, the western and eastern sites (442 and 444) received much more smectite that did Site 443. The cause could be local detrital supplies from the Iwo Jima and Kyushu-Palau Ridges, influenced by strong volcanic activity. Site $\mathbf{4 4 2}$ does not show abundant detrital supplies from Asia, which supports the idea of an emergent Kyushu-Palau Ridge, interfering with transport from the west. On the other hand, Site 443 sediments of this time contain fairly abundant chlorite, illite, and irregular mixed-layer clays whose Japanese origin is probable and favored by the site location on a submarine elevation, more northerly than both other sites.

The Pliocene distribution of clay minerals shows the same contrast between Sites 442 and 443 as for the late Miocene. Site 442 is under the essential influence of volcanogenic supplies (smectite), and westerly continental minerals are rather poorly represented; this suggests continuation of subaerial erosion of the Kyushu-Palau Ridge, which forms a barrier against Asiatic detrital contributions. On the other hand, Site 443 and Site 444 together receive more illite and chlorite than previously; the rareness of these minerals at the western site (442) and the essentially volcanic nature of the eastern outer arc point to a major Japanese detrital contribution at this time in the Cenozoic in the eastern part of the Shikoku Basin. This supposes a decrease of volcanic activity on the Iwo Jima Ridge, possibly contemporaneous with partial submersion. Note that the probable formation of the Nankai Trough in the early Pliocene (Karig, Ingle, et al., 1975) is not reflected by clay sedimentation in the Shikoku Basin, probably because of the mainly hemipelagic regime of terrigenous sedimentation.

During the early Pleistocene, conditions of clay sedimentation rapidly changed in the western part of the Shikoku Basin: Asiatic supplies, marked by vermiculite, primary minerals, and mixed-layer clays, largely reached the Site 442 area; this suggests a major stage of submersion of the Kyushu-Palau barrier, also responsible for the decrease in local smectite supply. At the same time, sedimentary minerals became more diversified at the three sites, which indicates facility of marine transport, overshadowing local supplies from island arcs. This general trend increases at the beginning of late Pleistocene time, when the submarine morphology seemingly was similar to the present one. Clay mineralogy at Site 442 became more common and dominated by western detrital supplies (Asiatic vermiculite), suggesting rapid submersion of the Kyushu-Palau Ridge to its present depth. Clay mineralogy at Sites 443 and 444 is not very different from that at Site 442 , and is only distinguished by an eastern supply of smectite issued from the nearby outer arc. In a general way, the decrease of marine bar- 
riers facilitates marine exchanges and mineralogical homogenization of detrital supplies.

To summarize, changes in detrital clay sedimentation with time at the three sites in Shikoku Basin drilled during Leg 58 appear to reflect physiographic changes since the formation of the northern Philippine Sea. The interpretation of available data is summarized on Figure 9. The main cause of mineralogical variations recorded in the marine sediments is the formation and then the diminution of submarine barriers (volcanic ridges), which influenced the oceanic circulation, and controlled sediment sources and resedimentation mechanisms. The most important structures intervening since the middle Miocene are the Iwo Jima-Bonin and the Kyushu-Palau Ridges; the latter appears to have been very active until the late Pliocene, and then to have subsided to two stages during the Pleistocene.

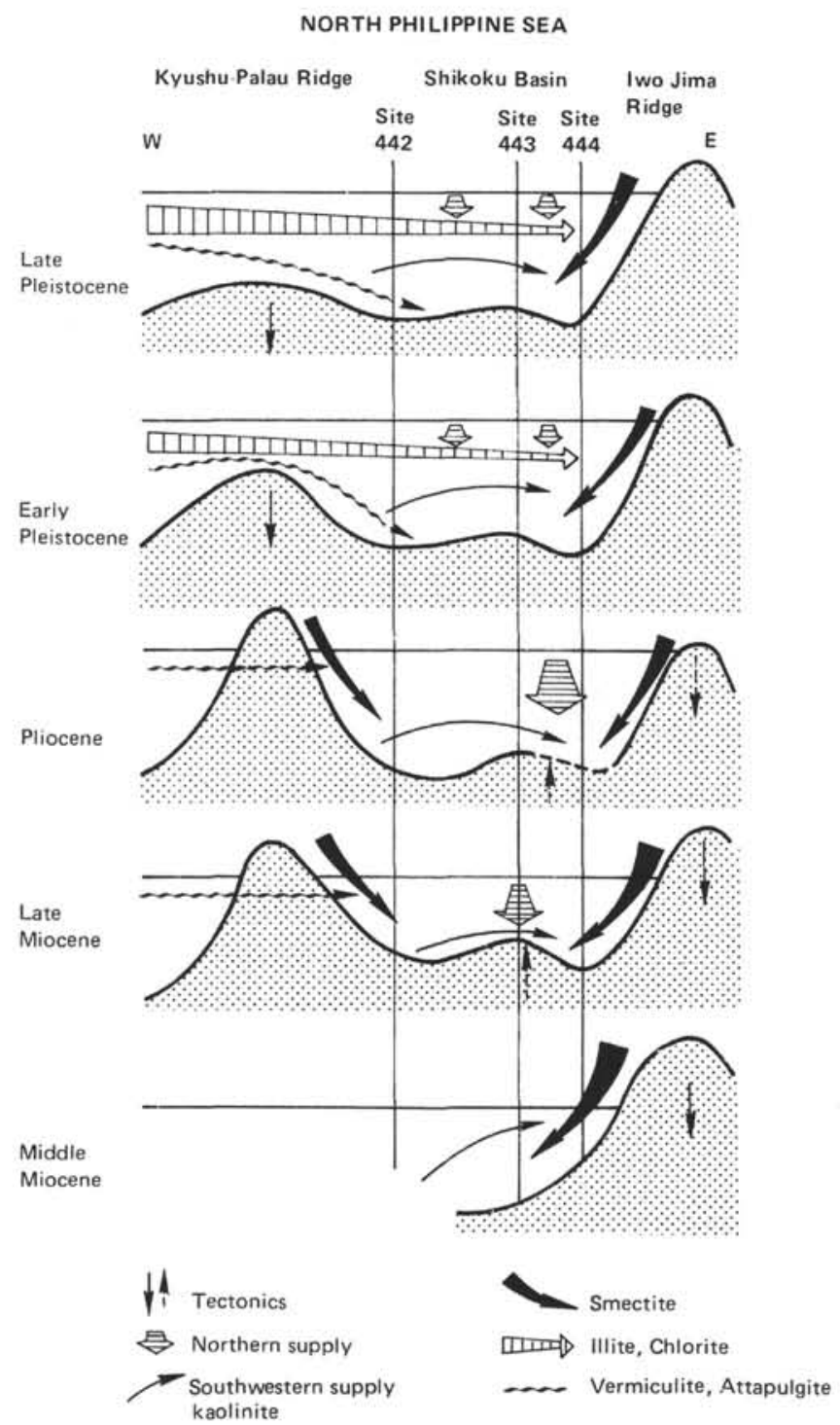

Figure 9. Interpretation of the main geographic variations in clay sedimentation with time in the Shikoku Basin.

\section{ACKNOWLEDGMENTS}

I acknowledge the U. S. National Science Foundation and IPOD-France for permitting me to participate on DSDP Leg 58. I am grateful to the entire Leg 58 scientific and technical shipboard party for helping me in many ways during the cruise. Financial support for this study was given by CNEXO (France) through grants $77 / 5489$ and $78 / 5708$, and by DGRST (France) through grant 78-7-2941. I gratefully acknowledge M. Acquaviva, J. Carpentier, F. Dujardin, C.-H. Froget, M. Picart, J.-P Ripert, N. Varin, and M. Vieille for technical assistance; C. Courtois for scientific help; and P. Debrabant and C. Latouche for pertinent review of manuscript.

\section{REFERENCES}

Aoki, S., 1976. Clay mineral distribution in sediments of the gulf of Thailand and the South China Sea. J. Oceanogr. Soc. Japan, 32, 169-174.

Aoki, S., and Oinuma, K., 1974. Clay mineral compositions in recent marine sediments around Nansei-Kyoto islands, south of Kyushu, Japan. J. Geol. Soc. Japan, 80, 57-63.

Aoki, S., Oinuma, K., and Sudo, T., 1974. The distribution of clay minerals in the recent sediments of the Japan sea. Deep Sea Res., 21, 299-310.

Beutelspacher, H., and van der Marel, H. W., 1968. Atlas of Electron Microscopy of Clay Minerals and Their Admixtures: Amsterdam (Elsevier).

Bonatti, E., Kolla, V., Moore, W. S., and Stern, C., 1979. Metallogenesis in marginal basins: Fe-rich basal deposits from the Philippine Sea. Mar. Geol., 32, 21-37.

Chamley, H., 1971. Recherches sur la sédimentation argileuse en Méditerranée., Sci. Géol., Strasbourg, Mém. 35. 1979. North Atlantic clay sedimentation and paleoenvironment since the late Jurassic. In Second Ewing Symposium: New York (Am. Geophys. Union), pp. 342-361.

Chamley, H., Debrabant, P., Foulon, J., Giroud d'Argoud, G., Latouche, C., Maillet, N., Maillot, H. and Sommer, F., 1979. Mineralogy and geochemistry of Creataceous and Cenozoic Atlantic sediments off the Iberian Peninsula (Site 398, DSDP Leg 47, Pt. 2). In Ryan, W. B. F., Sibuet, J.-C., et al., Init. Repts. DSDP, 47, Pt. 2: Washington (U. S. Govt. Printing Office), pp. 429-449.

Courtois, C., and Hoffert, M., 1977. Distribution des terres rares dans les sédiments superficiels du Pacifique sud-est. Bull. Soc. Géol. France, 19, 1245-1251.

Cook, H. E., Zemmels, I., and Matti, J. C., 1975. X-ray mineralogy data, far western Pacific, Leg 31 Deep Sea Drilling Project. In Karig, D. E., Ingle, J. C., et al., Init. Repts. DSDP, 31: Washington (U. S. Govt. Printing Office), pp. 883-895.

Cronan, D. S., 1973. Basal ferruginous sediments cored during Leg 16, Deep Sea Drilling Project. In van Andel, T. H., Heath, G. R., et al., Init. Repts. DSDP, 16: Washington (U. S. Govt. Printing Office) pp. 601-604.

Debrabant, P., Chamley, H., Foulon, J., and Maillot, H., 1979. Mineralogy and geochemistry of upper Cretaceous and Cenozoic sediments from North Biscay Bay and Rockall Plateau (Eastern North Atlantic), DSDP Leg 48. In Montadert, L. C., Roberts, D. G., et al., Init. Repts. DSDP, 48: Washington (U. S. Govt. Printing Office), pp. 703-726.

Gard, J. A., 1971. The Electron-Optical Investigation of Clays: London (Mineral. Soc.).

Griffin, J. J., Windom, H., and Goldberg, E. D., 1968. The distribution of clay minerals in the world ocean. Deep Sea Res., 15, 433-459. 
Hein, J. R., Scholl, D. W., and Gurmacher, C. E., 1975. Neogene clay minerals of the far NW Pacific and Southern Bering Sea: sedimentation and diagenesis. Proc. Internat. Clay Conf., pp. 71-80.

Huang, T.-W., and Chen, P.-Y., 1975. The abyssal clay minerals in the West Philippine Sea. Acta Oceanogr. Taiwanica, $5,37-63$.

Karig, D. E., Ingle, J. C., et al., 1975. Init. Repts. DSDP, 31: Washington (U. S. Govt. Printing Office).

Kobayashi, K., Oinuma, K., and Sudo, T., 1964. Clay mineralogy of recent marine sediments and sedimentary rocks from Japan. Sedimentology, 3, 233-239.

Kolla, V., Nadler, L., and Bonatti, E., in press. Clay mineral distributions in surface sediments of the Philippine Sea. Oceanologica Acta.

Mélières, F., 1978. X-ray mineralogy studies, Leg 41, Deep Sea Drilling Project, Eastern North Atlantic Ocean. In Lancelot, Y., Seibold, E., et al., Init. Repts. DSDP, 41: Washington (U. S. Govt. Printing Office), pp. 1065-1086.

Millot, G., 1964. Géologie des Argiles: Paris (Masson).

Murdmaa, J. O., Demidenko, Y. L., Kurnosov, V. B., and Faustov, S. S., 1977. Composition and rates of accumulation of clayey sediments in the Philippine Sea. Oceanology, 17, 318-321.

Paquet, H., 1969. Evolution géochimique des minéraux argileux dans les altérations et les sols des climats méditer- ranéens et tropicaux à saisons contrastées. Mém. Serv. Carte géol. Als. Lorr., Strasbourg, 20.

Peterson, M. N. A., and Griffin, J. J., 1964. Volcanism and clay minerals in the southeastern Pacific. J. Mar. Res., 22, 13-21.

Rex, R. W., Eklund, W. A., and Jamieson, I. M., 1971. X-ray mineralogy studies-Leg 6. In Fischer, A. G., Heezen, B. C., et al., Init. Repts. DSDP, 6: Washington (U. S. Govt. Printing Office), pp. 753-821.

Seyfried, W. E., Jr., Shanks, W. C., and Dibble, W. E., Jr., 1978. Clay mineral formation in DSDP Leg 34 basalt. Earth Planet. Sci. Lett., 41, 265-276.

Shackleton, N. J., and Kennett, J. P., 1975. Paleotemperature history of the Cenozoic and the initiation of Antarctic glaciation: oxygen and carbon analyses in DSDP Sites 277, 279 and 281. In Kennett, J. P., Houtz, R. E., et al., Init. Repts. DSDP, 29: Washington (U. S. Govt. Printing Office), pp. 743-755.

Thiede, J., 1977. Subsidence of aseismic ridges: evidence from sediments on Rio Grande Rise (Southwest Atlantic Ocean). Am. Assoc. Petrol. Geol. Bull., 61, 929-940.

Timofeev, P. P., Eremeev, V. V., and Rateev, M. A., 1978. Palygorskite, sepiolite, and other clay minerals in Leg 41 oceanic sediments: mineralogy, facies and genesis. In Lancelot, Y., Seibold, E., et al., Init. Repts. DSDP, 41: Washington (U. S. Govt. Printing Office), pp. 1087-1101.

PLATE 1

Site 442 Electron Micrographs

Figure $1442 \mathrm{~A}-3-4,40 \mathrm{~cm}$. Late Pleistocene gray mud. Much illite and mixture of chlorite, vermiculite, smectite, kaolinite and mixed-layer clays.

Figure $2442 \mathrm{~A}-21-4,10 \mathrm{~cm}$. Pliocene yellowish brown mud. Smectite and illite, accompanied by a mixture of mixed-layer clays, kaolinite, chlorite.

Figure $3442 \mathrm{~A}-30-3,10 \mathrm{~cm}$. Early Miocene dark brown pelagic clay. Smectite and fibrous clays.

Figure 4 442B-6,CC. Altered basalt. Large and broad wellshaped smectite sheets (saponite). 
PLATE 1
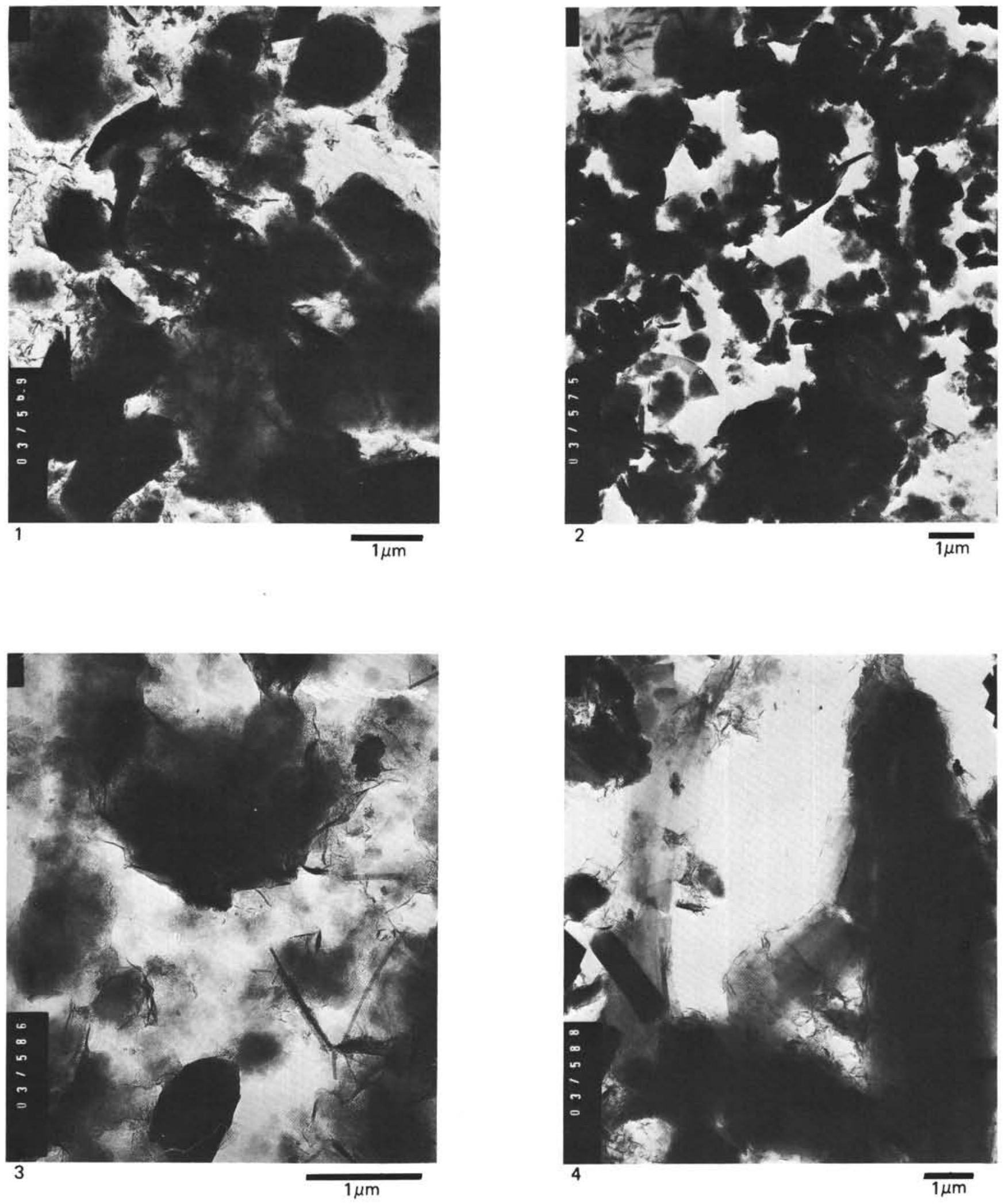
PLATE 2

Site 444 Electron Micrographs

Figures 1-4 444A-23-1, $50 \mathrm{~cm}$. Middle-Miocene reddish-brown nannofossil clay. Smectite (saponite?) and laths of probable attapulgite and (or) possible pyrophyllite. Additional common phyllites. 


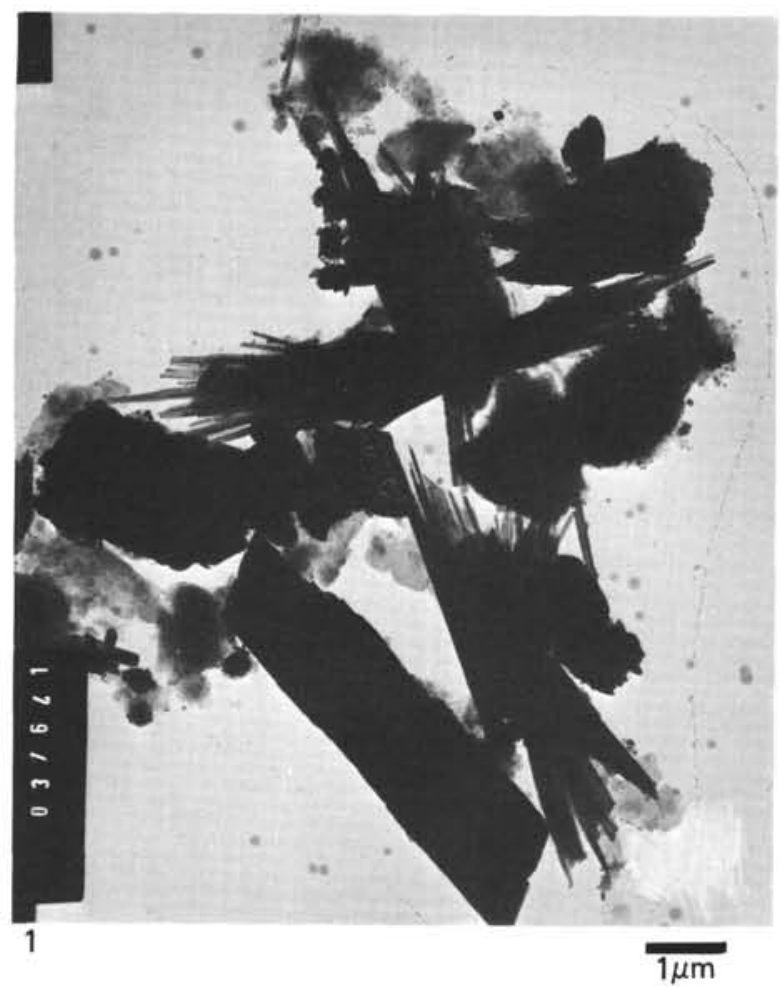

PLATE 2
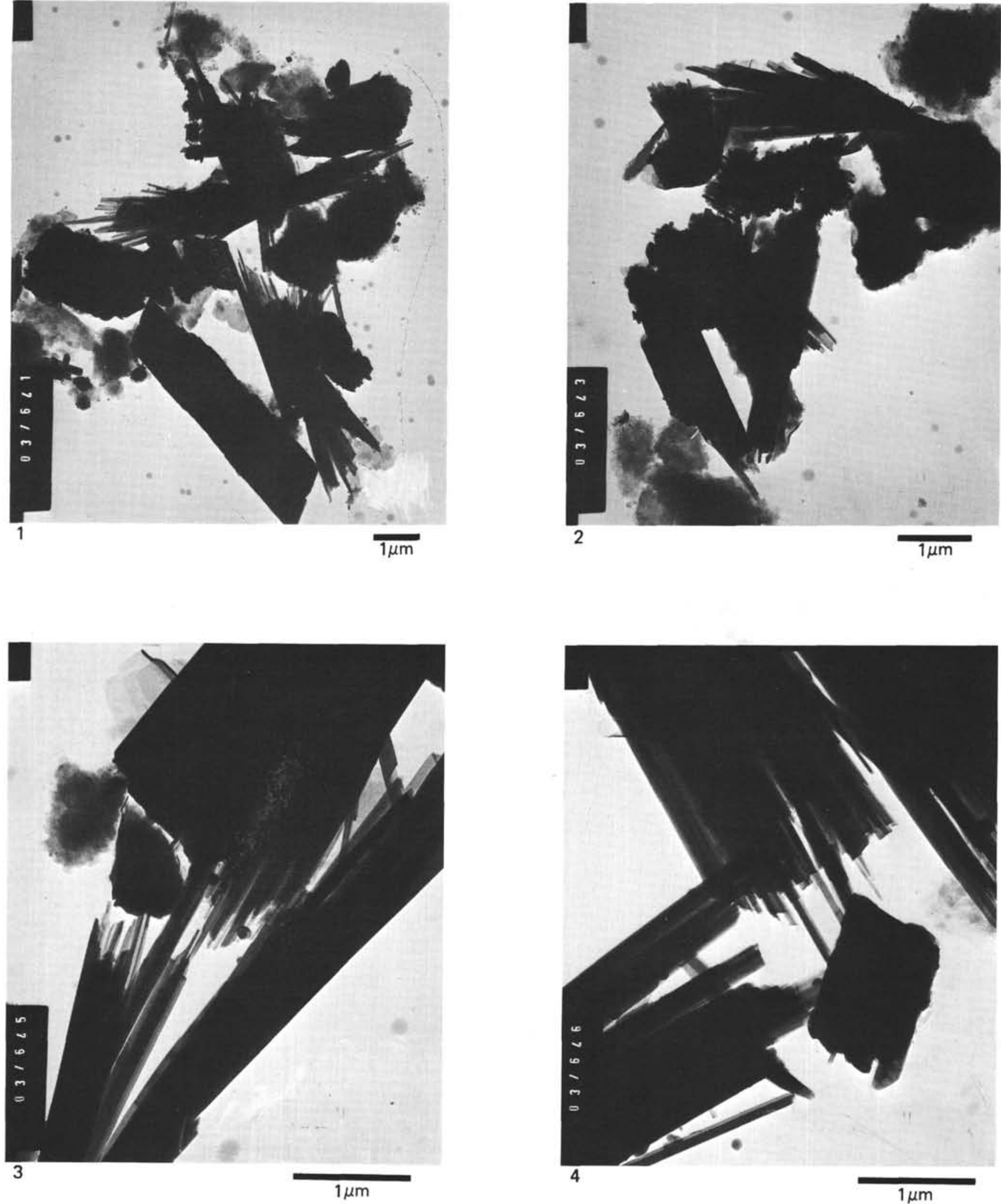